\title{
An Analysis on Perspectives of Investors on Commodity Trading and Risk Management in India
}

\author{
D. Shree Jyothi, D. Srinivasa Rao
}

\begin{abstract}
Indian commodity market has seen tremendous growth over the past few decades. Investment in capital market attracts higher risk as the return is higher. It becomes very important to understand the perspectives of theinvestors in market in order to minimize the risk faced. This will help them accomplish their goal of achieving higher return by minimizing the risk. The aim of the paper is to provide the risk management perspectives of commodity investors in India. The study concentrates on the aspects like the market and exchange selected for trading, types of risks faced, method of analysis, technique used for managing risk, percentage of the investment, advantages and disadvantages of trading in commodity trading etc. The results can be used by the commodity investors in taking wiser decisions in commodity derivatives investment.Also, hedge their risk accordingly.
\end{abstract}

Index Terms: Commodities, risk, market, exchange, source.

\section{INTRODUCTION}

Financial Market is the important component of the financial system of India which plays a significant role in the economic development. Derivatives are the financial instruments which do not have their own value but take the value from the underlying assets like equity, livestock, bullion, wheat, Foreign Exchange etc. Commodity derivatives are one of the important types of derivatives traded in the five national exchanges and the regional exchanges. Though its roots were laid in 1875 by the Bombay cotton Trade Association Ltd but formally organized trading started in 2003. The present paper aims to study the perspectives of the commodity investors concentrating on the aspects like the market and exchange selected for trading, types of risks faced, method of analysis, technique followed for managing risk, percentage of the investment, advantages and disadvantages of trading in commodity trading etc. The results can be used by the commodity investors in taking wiser decisions in commodity derivatives investment.

Research Gap: The earlier research concentrated mainly on the price discovery mechanism and the co-integration between spot price and futures price. Hence, the present study gains importance in terms of providing the information on the perspectives of commodity investors in India.

Revised Manuscript Received on July 09, 2019.

D. Shree Jyothi, D. Srinivasa Rao

Research Scholar, KL Business School, KLEF (Deemed to be University), Vijayawada, Professor, KL Business School, KLEF (Deemed to be University), Vijayawada.

\section{LITERATURE REVIEW}

Eduardoborensztein and Carmen. Reinhar[3],have provided a framework to explain impact of the demand and supply on commodity prices. Also, concluded stating the demand factors are the main fundamentals for commodity prices.Brajesh Kumar, Ajay Pandey[1], have studied in the paper the cointegration between the Indian commodity future markets with their world counterparts for nine agricultural products. It is found that all the commodities had linkage with other exchanges in world. RogerJ. B.Wets Ignacio Rios[4],have given a stochastic process which would estimate the copper prices. The model considers inflation adjusted prices and can be applicable for other commodity prices also. X.E.Xu.H.G.Fund [2], have conducted a bivariate asymmetric GARCH model to compare the precious metals future contracts traded in Chinese and Japanese markets. It is observed from the results that there is a great volatility spillover across both markets. It was evident from the study that, there is intraday pricing information transfer between the markets, Isita Mukherjee and Bhaskar Goswami[5], observed the volatility of the daily return of select commodities. Four commodities were considered and it was found that maturity effect is only valid for gold returns. Bojana Vukovic,Kristina Mijic[6], concluded that rational decisions in investment process. He suggested that risks in investments can be reduced to a minimum level when they are identified, assessed, monitored and avoided. Dr. Periasamy[7], has studied the perception of investors in commodity derivatives market. He analysed the investment pattern of investors in Chennai City, the factors influencing the spot and Futures and have made some suggestions to them.

\section{DATA SOURCES AND METHODOLOGY OF THE STUDY}

The study was analytical and descriptive in nature. Data is collected from primary sources from a sample of 512 commodity investors through a structure questionnaire. The data was collected by adopting simple random sampling method. Statistical tools like Frequency, ranking analysis are used to analyze the data. 
The statistical software's used are Excel and IBM SPSS 23

\section{DATA ANALYSIS AND FINDINGS}

The Indian commodity market has transformed from a situation where price was determined by the suppliers but now price is determined by the investors. The increase in the number of investors would clearly show that demand for commodity trading has increased. Commodity derivatives are taken as one of the investment avenue today and preferred by investors who look for higher return. Commodity futures are more in demand though options are still in the process of acceptance due to its advantages since the permission granted in 2016 only. The tables below depict the various perspectives of the commodity investors. The analysis is performed using the Friedman's ranking analysis and multiple response frequency methods as the respondents were given the choice to select multiple options.

Table1:

\begin{tabular}{|c|c|c|c|}
\hline \multicolumn{4}{|c|}{ Source of Information } \\
\hline & & Responses & Column N \% \\
\hline \multirow[t]{5}{*}{ \$Source_of_Information } & Source_FinWeb & 398 & $77.7 \%$ \\
\hline & Source_Brokfirm & 386 & $75.4 \%$ \\
\hline & Source_Newspaper & 385 & $75.2 \%$ \\
\hline & Source_WithMgr & 62 & $12.1 \%$ \\
\hline & Total & 1231 & $100.0 \%$ \\
\hline
\end{tabular}

\section{Source: Author's Calculation}

Inference:The interest and confidence of investment is developed through the sources of information which help the investor get the inputs required. It is observed from table 1 that Finance websites, information from brokerage firms and newspapers are the important sources of information considered by commodity investors.

Table 2: Preference of Investment

\begin{tabular}{|l|r|}
\multicolumn{2}{|c|}{ Ranks } \\
\hline \multicolumn{2}{|c|}{ Mean Rank } \\
\hline Pref_FD & 3.28 \\
Pref_MF & 5.60 \\
Pref_Equity & 6.71 \\
Pref_Comm & 4.66 \\
Pref_FinDerv & 5.23 \\
Pref_Insur & 3.35 \\
Pref_ReEstate & 3.19 \\
Pref_Gold & 3.99 \\
\hline
\end{tabular}

\section{Source: Author's Calculation}

\begin{tabular}{|l|r|}
\multicolumn{2}{|c|}{ Test Statistics $^{\mathbf{a}}$} \\
\hline N & 512 \\
Chi-Square & 1124.272 \\
df & 7 \\
Asymp. Sig. & .000 \\
\hline
\end{tabular}

a. Friedman Test

\section{Source: Author's Calculation}

Inference: In India investors can be classified into three types risk averse, risk neutral and risk takers. Depending on their risk taking ability they select the avenue for investment. As we know higher the risk higher the return. Friedman's Rank Analysis is conducted on the investor's responses and it is observed that their order of preference in investment is Equity, Mutual Funds, Financial Derivatives, and Commodity derivatives, Gold, Insurance, Deposit and Real Estate respectively. Test statistics show that the test is significant as $(\mathrm{p}<0.05)$. Looking at the preference shown in Table 2 the respondents are mostly risk takers as majority of them have selected Equity.

Table 3:

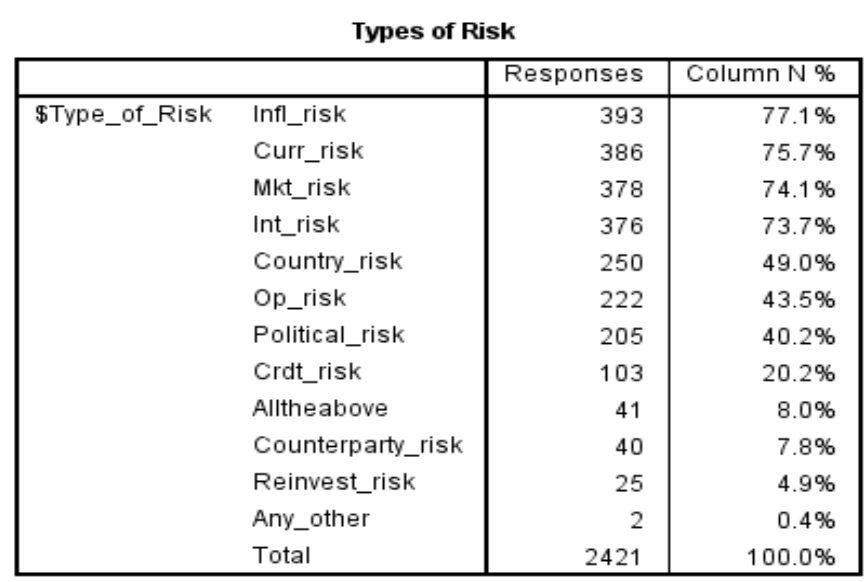

Source: Author's Calculation

Inference: Risk is variability in returns and the respondents were asked to select the various types of risks which they would face while investing in commodity derivatives. Respondents were allowed to select multiple options. Multiple response test in SPSS is conducted to find out and generalize the major types of risks they would encounter and it is observed from the above table 3 that Inflation risk, Currency risk, Market risk, Interest rate risks are the major risks faced while investing in commodities.

Table 4:

\begin{tabular}{|l|r|r|} 
Exchange for trading \\
\begin{tabular}{|ll|r|r|}
\hline & Responses & Column N \% \\
\hline \$Exchange & Exchange_MCX & 462 & $90.8 \%$ \\
& Exchange_NCDEX & 304 & $59.7 \%$ \\
Exchange_NMCE & 43 & $8.4 \%$ \\
Exchange_UCX & 23 & $4.5 \%$ \\
Exchange_ICEX & 20 & $3.9 \%$ \\
Exchange_Regional & 16 & $3.1 \%$ \\
Exchange_ACE & 9 & $1.8 \%$ \\
Exchange_Anyother & 0 & $0.0 \%$ \\
Total & 877 & $100.0 \%$ \\
\hline
\end{tabular}
\end{tabular}

\section{Source: Author's \\ Calculation}


Inference: Commodity investors are required to select a market place for trading and it is observed from table 4 that MCX and NCDEX are the preferred national exchanges they select for trading in commodity derivatives.

\section{Table 5:}

Type of commodity selected for irmestment

\begin{tabular}{|ll|r|r|}
\hline & & Responses & Column N \% \\
\hline \$Commodity_type & Comm_type_Precious & 385 & $75.5 \%$ \\
& Comm_type_industrial & 279 & $54.7 \%$ \\
& Comm_type_Agro & 274 & $53.7 \%$ \\
Comm_type_Energy & 264 & $51.8 \%$ \\
Comm_type_soft & 194 & $38.0 \%$ \\
Comm_type_Allabove & 10 & $2.0 \%$ \\
Comm_type_Anyother & 3 & $0.6 \%$ \\
Comm_type_Live_stock & 0 & $0.0 \%$ \\
Total & 1409 & $100.0 \%$ \\
\hline
\end{tabular}

\section{Source: Author's Calculation}

Inference: Trading in India happens in types of commodity as listed in the table 5 and observed that the commodities like precious metals, industrial metals, Agro products and Energy are popular commodities for trading.

Table 6a:Level of risk in the investments

\begin{tabular}{|l|c|}
\multicolumn{2}{|c}{ Ranks } \\
\hline \multicolumn{2}{|c|}{ Mean Rank } \\
\hline FD_risk_level & 2.16 \\
MF_risk_level & 4.17 \\
Equity_risk_level & 5.92 \\
Comm_risk_level & 6.20 \\
FinDerv_risk_level & 6.84 \\
Insur_risklevel & 3.04 \\
ReEstate_risklevel & 4.72 \\
Gold_risklevel & 2.95 \\
\hline
\end{tabular}

Source: Author's Calculation

\section{6b:Significance of Friedman test for risk level in} investments

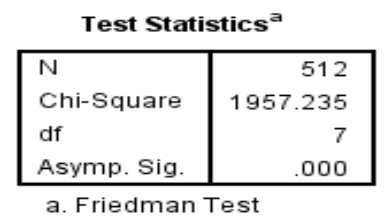

\section{Source: Author's Calculation}

Inference: Respondents opinion was taken to find out the level of risk they assume for each of the investment avenues and Friedman's Rank Analysis is conducted on the investor's responses. It is observed from Table 6 that risk level according to them is highest in Financial Derivatives, commodity derivative and equity respectively.Test statistics show that the test is significant as $(\mathrm{p}<0.05)$

Table 7:

Method of analysis considered for imvestment in commodities
\begin{tabular}{|ll|r|r|}
\hline & Responses & Column N \% \\
\hline \$Method_of_Analysis & Method_Expertsadv & 350 & $69.3 \%$ \\
& Method_Fundamental & 227 & $45.0 \%$ \\
& Method_Technical & 204 & $40.4 \%$ \\
& Method_Both & 199 & $39.4 \%$ \\
& Method_Allabove & 26 & $5.1 \%$ \\
& Method_Anyother & 5 & $1.0 \%$ \\
& Total & 1011 & $100.0 \%$ \\
\hline
\end{tabular}

\section{Source: Author's Calculation}

Inference: Respondents were asked about the method of analysis of advice they conduct for investment in commodities. They were allowed to select more than one option. Based on multiple response frequencies, commodity investors feel experts' advice is the best method of analysis for investment and next preference is Fundamental and Technical Analysis.

\section{Table 8:}

Source of advice for imvestment in commodities
\begin{tabular}{|ll|r|r|}
\hline & & Responses & Column N \% \\
\hline \$Source_of_Advice & Advice_Newspaper & 416 & $81.6 \%$ \\
& Advice_Brokers & 395 & $77.5 \%$ \\
& Advice_Television & 300 & $58.8 \%$ \\
& Advice_Friends & 277 & $54.3 \%$ \\
& Advice_Magazines & 176 & $34.5 \%$ \\
& Advice_Anyother & 7 & $1.4 \%$ \\
& Total & 1571 & $100.0 \%$ \\
\hline
\end{tabular}

\section{Source: Author's Calculation}

Inference: Respondents were asked to select the source of advice they prefer before they invest in commodity derivatives. Based on multiple response frequencies, investors feel advices for investment in commodities are given best in newspapers and by the brokers as mentioned in Table 8 .

Table 9:

\begin{tabular}{|l} 
Technique used for managing risk in irvestment \\
\begin{tabular}{|ll|r|r|}
\hline \multicolumn{1}{|c|}{} & Responses & Column N \% \\
\hline \$Technique_Risk_Manag & Technq_ExitMinloss & 401 & $78.3 \%$ \\
ement & Technq_Diversification & 377 & $73.6 \%$ \\
& Technq_Avoidance & 304 & $59.4 \%$ \\
& Technq_Invest_with_tren & 300 & $58.6 \%$ \\
d & 219 & $42.8 \%$ \\
Technq_Avgdown & 160 & $31.3 \%$ \\
& Technq_Ignorerisk & 62 & $12.1 \%$ \\
& Technq_Hedging & 3 & $0.6 \%$ \\
& Technq_Anyother & 1826 & $100.0 \%$ \\
\hline
\end{tabular}
\end{tabular}

\section{Source: Author's Calculation}

Inference: Risk is commodities is high and there are various techniques 
used for minimizing the risk in the investment made in commodities. Respondents were asked to select at least one technique and based on multiple response frequencies, it is observed from Table 9 that Exit with minimum loss and Diversification are the best risk management techniques used by investors.

Table 10:

Advantages of imvesting in commodities
\begin{tabular}{|ll|r|r|}
\hline & Responses & Column N \% \\
\hline \$Advantages & Adv_HighLiquidity & 370 & $72.3 \%$ \\
& Adv_LowInvestment & 360 & $70.3 \%$ \\
& Adv_HighReturn & 237 & $46.3 \%$ \\
Adv_Pricediscovery & 139 & $27.1 \%$ \\
Adv_transferability & 90 & $17.6 \%$ \\
Adv_Anyother & 13 & $2.5 \%$ \\
Total & 1209 & $100.0 \%$ \\
\hline
\end{tabular}

Source: Author's Calculation

Inference: Advantages are the motivators for investment in a particular instrument. Commodity derivatives have many advantages and the respondents are asked to select more than one advantage which they feel motivated them to invest. Based on multiple response frequencies, it is observed from Table 10 that High liquidity and low investment are the major advantages of investing in commodity derivatives.

Table 11:

\begin{tabular}{|c|c|c|c|}
\hline \multicolumn{4}{|c|}{ Disadvantages of imvesting in commodities } \\
\hline & & Responses & Column N\% \\
\hline \multirow[t]{8}{*}{ \$Disadvantages } & $\begin{array}{l}\text { Disadv_Returns_not_ass } \\
\text { ured }\end{array}$ & 361 & $70.6 \%$ \\
\hline & Disadv_Stdcontracts & 329 & $64.4 \%$ \\
\hline & Disadv_Volatile & 297 & $58.1 \%$ \\
\hline & Disadv_Highcontractsize & 297 & $58.1 \%$ \\
\hline & Disadv_Complexity & 261 & $51.1 \%$ \\
\hline & Disadv_Risky & 240 & $47.0 \%$ \\
\hline & Disadv_Anyother & 11 & $2.2 \%$ \\
\hline & Total & 1796 & $100.0 \%$ \\
\hline
\end{tabular}

Source: Author's Calculation

Inference: Every coin has two faces and commodity derivatives also. When there are advantages there are disadvantages too. Respondents were asked to select more than one disadvantage. Based on multiple response frequencies, it is observed from Table 11 that Returns not assured and standardized contracts are the major disadvantages of investing in commodity derivatives.

Table 12:

\begin{tabular}{|c|c|c|c|}
\hline \multicolumn{4}{|c|}{ Market for trading in commodities } \\
\hline & & Responses & Column N \% \\
\hline \multirow[t]{5}{*}{ \$Market_for_trading } & Mrkt_Futures & 443 & $86.5 \%$ \\
\hline & Mrkt_physical & 101 & $19.7 \%$ \\
\hline & Mrkt_options & 87 & $17.0 \%$ \\
\hline & Mrkt_Anyother & 1 & $0.2 \%$ \\
\hline & Total & 632 & $100.0 \%$ \\
\hline
\end{tabular}

Source: Author's Calculation

Inference: In India Futures market existed from 2003 but Options were permitted in 2016. Due to late beginning options in spite of their advantages over futures are gaining importance from the investors. Respondents were asked to select more than one market they prefer for investing. Based on multiple response frequencies, it is observed from Table 12 that Futures market is the most preferred market for trading in commodity derivatives.

Table 13: Type of traders in Commodity derivatives market.

\begin{tabular}{|l|l|l|}
\hline $\begin{array}{l}\text { TYPE OF THE } \\
\text { TRADER }\end{array}$ & Frequency & Percent \\
\hline $\begin{array}{l}\text { Arbitrager(look for } \\
\text { opportunities to in }\end{array}$ & 67 & 13.09 \\
\hline $\begin{array}{l}\text { Hedger(invest with } \\
\text { calculation) }\end{array}$ & 95 & 18.55 \\
\hline $\begin{array}{l}\text { Speculator(invest in } \\
\text { expectation of profits) }\end{array}$ & 350 & 68.36 \\
\hline Total & 512 & 100.00 \\
\hline
\end{tabular}

Source: Author's Calculation

Inference: Derivative traders are classified into Arbitragers, Hedgers and Speculators J.C.Hull (2015). Respondents were asked to select the type they belong to. Based on frequencies, it is observed from Table 13 that majority of the respondents are speculators.

Table 14: Frequency of trading by the commodity investors.

\begin{tabular}{|l|l|l|}
\hline Trading & Frequency & Percent \\
\hline Daily & 60 & 11.72 \\
\hline Weekly & 158 & 30.86 \\
\hline Monthly & 148 & 28.91 \\
\hline Occasionally & 146 & 28.52 \\
\hline Total & 512 & 100.00 \\
\hline
\end{tabular}

Source: Author's Calculation

Inference: Respondents were asked to select the frequency of their trade and based on their responses, it is observed that majority of the 
investors are trading weekly, monthly but not daily like in equity. There are quite big numbers who trade occasionally also.

Table 15: Percentage of total investment in commodity derivatives

\begin{tabular}{|l|l|l|}
\hline $\begin{array}{l}\text { Percentage of } \\
\text { Investment in } \\
\text { Commodity } \\
\text { derivatives }\end{array}$ & Frequency & Percent \\
\hline$<25 \%$ & 341 & 66.60 \\
\hline $26-50 \%$ & 154 & 30.08 \\
\hline $51-75 \%$ & 154 & 30.08 \\
\hline$>75 \%$ & 12 & 2.34 \\
\hline Total & $\mathbf{5 1 2}$ & $\mathbf{1 0 0 . 0 0}$ \\
\hline
\end{tabular}

Source: Author's Calculation

Inference: Respondents when asked about the percentage of investment in commodity derivatives and based on their responses tabulated in Table 15 it is observed that majority of them areinvesting $<25 \%$ of the total investment.

Table 16: Classification of commodity derivatives market.

\begin{tabular}{|l|l|l|}
\hline $\begin{array}{l}\text { Classification of } \\
\text { Commodity } \\
\text { derivatives market }\end{array}$ & Freq. & Percent \\
\hline High Return-Low Risk & 39 & 7.62 \\
\hline High Return-High Risk & 369 & 72.07 \\
\hline Low Return-High Risk & 79 & 15.43 \\
\hline Low Return-Low Risk & 25 & 4.88 \\
\hline Total & 512 & 100.00 \\
\hline
\end{tabular}

Source: Author's Calculation

Inference: Respondents when asked to classify the commodity derivatives market. It is observed from Table 16 that commodity derivatives market is classified as High Return-High Risk investment by majority of the investors.

Table 17: Duration of association with the commodity derivative market.

\begin{tabular}{|l|l|l|}
\hline Duration & Freq. & Percent \\
\hline$<1$ Year & 133 & 25.98 \\
\hline $1-2$ years & 109 & 21.29 \\
\hline $2-3$ Years & 177 & 34.57 \\
\hline$>5$ Years & 13 & 2.54 \\
\hline
\end{tabular}

Respondents were asked about the tenure of their trading in commodities. Based on frequencies, it is observed from Table 17 that majority of the commodity investors have tenure less than less than 3 years.

\section{CONCLUSION}

A number of researches have been conducted concentrating on the price discovery mechanism, co-integration between the spot and future price and awareness of commodity derivatives. The significant volatility in the trading of these new instruments recommends for a study on the perspectives of investors on the trading patterns and their management of the risk faced. The present study focused on these aspects and the results are useful to select a commodity to invest, market to trade, percentage of investment to be made, source of information and advice to use for trading etc. These results are useful for commodity derivative investors while taking decisions in investments.

\section{REFERENCES}

1. Brajesh Kumar, Ajay Pandey, "International Linkages of the Indian commodity Futures Markets, Modern Economy, Vol 2,2011, pp 213-227

2. X.E.Xu.H.G.Fund, "Cross-Market Linkages between US and Japanese precious Metals Futures Trading”, International Financial Markets, Institution and Money, Vol 15,No.2, 2005,pp107-124.

3. Eduardoborensztein and Carmen. Reinhar, "The macroeconomic determinants of commodity prices", IMF Staff papers, Vol.41,No.2,June 1994

4. RogerJ. B.Wets Ignacio Rios, "Modeling and estimating commodity prices: copper prices”,Math FinanEcon,Vol 9,2015, pp247-270.

5. 5.Isita Mukherjee and Bhaskar Goswami, "The volatility of returns from commodity futures:eveidence from India, Financial Innovation, Vol 3, No. 15, 2017,pp 1-23.

6. Bojana Vukovic,Kristina Mijic, "Risk Management in the Investment process", International symposium Engineering Management and competitiveness, June,2011

7. Dr. Periasamy, "Perception of Investors toward Indian Commodity Derivative Market with Inferential Analysis in Chennai City", International Journal of Management Studies, Vol V,No. 3(3), 2018, pp 73-82

8. Lokara, S.M, “Commodity derivatives and price risk management: and empirical anecdote from India", Reserve Bank of India Occasional Papers, 28(2), 2017, pp 27-77

9. J.C. Hull, "Options, Futures and other derivatives", Ninth Edition, 2015 , Pearson 